\title{
Can a "Lone wolf" quasi-investigative journalist substitute low functionality of the law enforcement system?
}

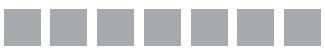 \\ Andrej Školkay
}

SCHOOL OF COMMUNICATION AND MEdIA, BratisLaVa, SLOVAKIA

DOI: 10.19195/1899-5101.9.2(17).4

\begin{abstract}
The present article analyzes a relatively unusual case, in which a quasi-investigative journalist, working in an entirely independent capacity, succeeded in uncovering and foiling an international money laundering attempt. This extremely significant story reveals the existence of a complex legal framework for tackling money-laundering operations in the EU. In this particular instance, local police and prosecutors were unable to take action against the perpetrator of illegal activity, as the case did not fulfill conditions of local legislation. The present study thus draws attention to the weakness of anti-corruption and anti-money laundering legislation. It provides evidence that a non-affiliated journalist can also be a great asset to society, although the actual mostly low coverage of the case indicates a poor media understanding of the social implications of crime detection across both the Czech Republic and Slovakia.
\end{abstract}

KEYWORDS: money laundering, undercover investigative journalism, anti-money laundering (AML), Slovakia, Czech Republic, Hong Kong.

\section{INTRODUCTION}

Research in the fields of media or politics seldom focuses on complex issues concerning both disciplines and many problems are sidelined in public, academic, professional, or media discourses. An example of such an issue is the outcome of individual investigative journalistic work proving low functionality of the legal system, ineffectiveness of the tools of state administration, and the failure of crime prevention. Within the broad framework of journalism, the scope of investigative journalism is vital to the proper functioning of political and economic systems. In reality, it acts as a beacon that highlights dysfunctions of the political and economic setup.

The case study under review is the extraordinary story of an Italian journalist, Tony Papaleo, who provided evidence to the Slovak and Hong Kong (HK) police, 
proving that Slovak "businessman" and "journalist" Juraj Jariabka hired him for a money laundering operation to be routed through HK/Chinese banks in 2013. Papaleo's effort resulted in a prompt prison sentence for Jariabka in HK. Papaleo, who performed a great service to society by preventing this instance of money laundering, sadly did not benefit in any way from the success of his independent investigative accomplishment. On the contrary, he lives in an impoverished state today, constantly fearful of being a target of revenge.

In-depth analysis of this case has brought two points to light: firstly, that the inability of the Slovakian police/prosecutors to put a check on the money laundering act was not entirely their fault - they were just obeying the law of the land. In addition, the lackadaisical attitude of the country's theoreticians and experts on the subject of AML was also apparent in this case. A little more initiative on the part of the legislature combined with meaningful intervention by experts could have probably promoted clarity and brought better results. Secondly, it was observed that a relatively low watch-dog mentality was displayed by both tabloid and standard media (except one Czech business oriented newspaper) which was coupled with their inability to focus on remedial measures or broader social/legislative implications. Though the tabloid media and business newspapers did highlight this case more frequently than the quality papers, their objective in doing so lay in sensationalism rather than calling for a beneficial modification of the legislature, or effecting a change in the approach of the police/prosecutors.

\section{METHODOLOGY}

Case study research entails investigation and analysis of a single or collective case, with the intention of capturing the complexity of the object of study. Ondrejkovic and Majerčíková (2012) attach great value to case study research, and foresee many possible challenges in its proper execution. George and Bennett (2004, p. 19) have identified four significant benefits that make case studies indispensable for the testing of hypotheses and, more importantly, for theory development: (1) their potential for achieving high conceptual validity; (2) their sound procedures for fostering new hypotheses; (3) their usefulness when closely examining the hypothesized role of causal mechanisms in the context of individual cases and (4) their capacity for addressing causal complexity.

Adopting multiple methods for data collection and analysis enhances development of the case, promotes clarity and comprehension, and thus offsets the disadvantages of the qualitative case study method (Stake, 1995, in Hyett \& DicksonSwift, 2014). George and Bennett (2004) term this as the method of process-tracing, i.e. tracing the links between possible causes and observed outcomes with the possibility of the strategy playing a heuristic role. Also, Ondrejkovič and Majerčíková (2012) perceive the scientific importance of a case study in its generality through induction; in a new case study, generalisation can be applied through the instrument 
of deduction. Case selection is a precursor to analysis of a case that needs to be presented as a convincing argument (Merriam, 2009, in Hyett \& Dickson-Swift, 2014).

The present case study was chosen due to its portrayal of the vital role of a journalist/media in fighting corruption and based on interviews with various journalists, academics and media watchdog activists, and also through a systematic search of corruption cases which were made public in Slovakia over the past 10 years (2004-2013). The huge number of available cases was categorised into four groups, depending on the role played by the journalist and according to the Corvinus University/University of Perugia typology: enforcer/initiator (positive role), reporter/facilitator (positive role), active corrupted/collaborator (negative role), and inactive/apathetic (negative role). This particular story was given preference as it seemed to be a sui generis (deviant) case, thus making it doubly interesting. The selected case is unique due to the fact that it does not fit into traditional definitions of corruption, i.e. it does not involve a public institution or public representative. Furthermore, this case was related to huge fraud - more than $€ 46$ million had been stolen from the Czech savings cooperative bank resulting in the loss of savings for many citizens.

Nevertheless, this one-of-a-kind story of quasi-investigative journalism and quasi-corruption is significant in suggesting complex legal strictures dealing with AML operations, and its precise but ultimately ineffective application by local state authorities. This is an important finding as it exposes the weak law enforcement system for handling corruption and AML activities which is in operation in Slovakia and possibly other EU countries with identical AML legislation. The multinational dimension of the case makes it interesting: the money was stolen in the Czech Republic, the money launderer was a Slovakian citizen, the agent was an Italian citizen, and the bank was located in Hong Kong. Consequently, diverse coverage occurred in various national media.

\section{ROLE OF THE JOURNALISTS}

The story, which reads like a best-seller, began in 2012 when Papaleo chose the cover identity of a morally bankrupt, corrupt and substance-abusing drug addict, quasi-journalist named "Tony Corleone". In disguise, Papaleo frequented night bars in Bratislava, Slovakia, for a year. One can only speculate whether this was a year-long undercover journalistic investigation, or a patient and purposeful "lying-in-wait" period for a potential victim. He seemed to have behaved more like a freelance detective than an investigative journalist.

In May 2013, an underworld acquaintance, Jozef "Dodo" Drlicka of Slovakian nationality but with Austrian citizenship, approached him with a job offer in Hong Kong. Soon afterwards, Papaleo got acquainted with Jariabka, a business friend of Drlicka, and was promised 5,000 EUR for being a "straw man" who would open accounts under his name in HK. Papaleo secretly recorded his discussions with 
Jariabka using a hidden camera (based on this evidence, the HK police would detain Jariabka in the immediate future). The footage played during the trial showed Jariabka and Drlicka convincing undercover agent Papaleo to take the job. Finally, Papaleo was taken to HK by Jariabka in 2013, and asked to set up bank accounts. Although Papaleo entered the banks, he only feigned setting up the accounts as he did not wish to participate in any criminal activity in HK.

Papaleo then reported the case to the Slovakian police but was dismissed, because Slovakian legislation does not consider an attempt at money laundering as a criminal offence unless there is money present in a bank account, or physically in cash. Papaleo also claims that Jariabka was connected to the most wanted Slovakian citizen by Interpol, and although he told this fact to the police, it did not change their decision. He therefore linked the refusal to the notion that Jariabka could have probably been connected to influential Slovakian businessmen with powerful political contacts (see Topky.sk, 2015). Nevertheless, this speculation cannot be proven and later analysis of Slovakian legislation seems to indicate that the unfortunate inability of the police to act against Jariabka was based on the strict application of the law.

Papaleo then approached the HK police which promptly started the investigation and successfully detained Jariabka shortly afterwards. In September 2014, the court sentenced him to 4 years in a HK jail as the first individual ever to be punished for money laundering in HK (SCMP, 2014).

The story of Papaleo has a multiple international dimension. Antonio Aldo "Tony" Papaleo is an Italian who worked in the Czech Republic and Slovakia as a journalist. More specifically, he worked as an editor and deputy editor of the only online business and general politics media published for Italian and English speaking foreigners living in the Czech Republic, Hungary and Slovakia. Papaleo was associated with the International Consortium of Investigative Journalists as a Regional Partner (for the Czech Republic and Slovakia). For some time, he was also a member of the Slovak Syndicate of Journalists (SSN), the largest journalistic organization in Slovakia, albeit with a poor reputation. Papaleo appreciated the rather inexpensive membership in all Slovak and Czech journalistic organizations, and lauded the fact that, in both countries, there was no compulsion for working journalists to be registered members of professional journalistic bars. This is in contrast to Italy where the employment of a journalist necessitates membership of the Italian Order of Journalists (ODG), which is a legally recognized "professional guild". It is a corporatist, state-approved association with tough eligibility conditions and a relatively high annual membership fee. When compared to other professional unions for journalists elsewhere in Europe, the Ordine dei Giornalisti is quite a unique institution. However, conditions laid down both by Italian law and market forces do not seem to be very beneficial for independent investigative journalists, which is true in spite of very encouraging and binding ethical-legal regulations for journalists (Ethic Net, 1963). 
A correlation seems to exist between the level of corruption in Italy, and the regulatory control over the country's media system. Suphachalasai (2005) reiterates that the employment decisions and output of media companies are determined by the extent of media freedom and competition, and the magnitude of corruption can quantify competition within the media industry, especially when rent-seeking bureaucracy (read as politicians) strive to benefit by suppressing competition in this arena. It appears that, in Italy, a rigid regulatory regime complicates entry into the labor journalistic market as an equal and fully paid professional, a scenario which seriously undermines the ability of journalism to tackle corruption.

Be that as it may, coming back to the international dimension of this case, the criminals had Slovakian, Czech, as well as Austrian citizenship, yet the money laundering attempt happened in HK. Also, the laundered money of dubious origin was supposed to come from the Czech Republic, although this was never proved in court. Evidence, however, confirms this hypothesis.

The present case study does not fit entirely into an established typology. Rather, it is more like a sui generis type of quasi-journalistic activity. However, the journalist did not play the typical role of agent-provocateur, and the criminals would have involved somebody else for the "dirty work" anyway. The journalist also contacted the police soon enough to get the tools to legally monitor the illegal activity, which would have thereby rendered it accountable in a court. The opportunity of publishing this story in the media first, however, eluded him. The role of this journalist is therefore closest to the enforcer/initiator (positive role) as he discovered and uncovered corruption (though it did not meet the norms of the standard definition of corruption), exposed criminal practices (which were not seen as a crime in the country where he worked, but considered so abroad), and in addition, participated in the corruption case as the pseudo-agent.

\section{INVESTIGATIVE JOURNALISM}

Metyková and Císařová (2009) reiterate that Eastern European journalists face changes and challenges related to the "proletarization" of journalistic work, commercial pressures, and "dumbing down", as well as changing work practices related to new technologies. Therefore, it is no surprise that Štetka and Örnebring (2013) found investigative journalism to be weak across Eastern Europe in general, in terms of autonomy and effects, although more powerful and well-established in countries with more stable and richer media markets (notably Estonia, Poland, and the Czech Republic).

Investigative journalism generally consists of four main characteristics: a) the report is based on the initiative and work of the journalist; b) the report is on matters of public interest; c) secrecy of derived information is sought by some people or institutions, and it has d) the potential to cause public outrage (Školkay, 2001). It is further characterized by lengthy preparation and research, combined with an an- 
alysis of social and legal issues. Key areas of interest for investigative journalists usually include crime, corporate wrongdoing, political corruption, and public policy.

In Slovakia, many opportunities exist for investigative journalism due to the ethics of governance coupled with the methods of state bureaucrats. Quoting the main culprit as a low transparency, Nicholson (2001) opines that from the media point of view, the problem is mainly one of internal ethics. He also claims that journalists in Slovakia face political, economic and social pressure, insomuch that their work lacks precision and freedom, and face a conflict of interest. Despite the need of journalists to "serve the readers", the published work is often influenced by vested interests of politicians and media owners who wish to fulfill personal or professional ambitions (Nicholson, 2001). Very often, journalists also write and publish articles to oblige requests for publicity, thereby assuming the role of advertiser. In general, it appears that most investigative stories are actually based on leakage of vital information.

Petková (2013), one of the few investigative journalists in Slovakia, observes that one of the many reasons for the small number of professional investigative journalists is that publishers cannot afford to pay journalists who would be devoted to full-time investigation. In her opinion, Slovakia does not yet display a tradition of investigative journalism, possibly because the freedom of speech and expression have been prevalent for a shorter timespan in comparison to other nations such as the UK. Žitný (2004) also recognizes problems on the legal front, as many investigative journalists are not employed on regular contracts. As a result, they cannot seek protection with the help of lawyers or a publisher if necessary, which only increases the reluctance to work on controversial subjects. The lack of support for investigative journalists by Slovakian media houses thus seems to be caused both by financial as well as legal issues.

Despite the fact that investigative journalism is globally recognized as a vital part of a functional and liable democratic society, the problem of its underdevelopment in Slovakia (and some other countries) probably lies in the prevalent public and governmental attitude which does not foster such journalists by any means for the most part. Yet responsibly aimed governmental or, more importantly, nongovernmental support or funding backed by improvement of legal inconsistencies would certainly help to increase the number of high quality investigative journalists and their impact on society. If the media market itself cannot, or does not want to, recognize their social and political importance, consolidation of journalists could bring some positive results in the area. Also, the finding of more innovative sources of funding (such as donor-based or crowd fundraising, project journalism, membership dues, or commercial media fees) may actually be the crucial remedy to decrease dependency on mostly reluctant and profit-oriented media houses.

Nevertheless, and relating back to the specific case under review, it can be concluded that Papaleo actually did not meet the definition of investigative journalist. He did not publish a story about this case before he approached the police, probably due to the fear of revenge and keeping in mind the magnitude of crime he had 
uncovered. Avoidance of a libel suit could be another reason, as he had recorded some talks with Jariabka without prior official permission, and such an act is considered illegal by Slovakian legislation. Papaleo was thus in possession of incriminating evidence which he could not use before the court, and any attempt to do so would have been self-destructive.

\section{THE CRIME OF MONEY LAUNDERING}

Regulations governing money laundering have become stricter over the last three decades and started to invite participation from more and more actors (Unger \& Hertog, 2012). Governments and law enforcement bodies have developed an increasingly global, intrusive, and routine set of measures to thwart and discourage money laundering attempts. However, little is known about the outcomes of this system on laundering methods. The AML regime does facilitate investigation and prosecution of some criminal participants who would otherwise evade justice, but to a lesser degree than would be expected by advocates of "follow the money" methods (Levi \& Reuter, 2006).

Unger (2013) claims that over the last two decades, money laundering could hardly have decreased, possibly due to the broadening of the concept of money laundering itself. Very little professional laundering occurs in illicit markets. In some areas, such as the drugs trade, most individuals indulge in self-laundering and, contrary to other market roles, launderers are not particularly central players (Malm \& Bichler, 2013). However, Soudijn's (2014) research indicates that professional money launderers are often engaged in the trade (almost half of the files indicate the presence of such "specialists"), although the research data does not imply the absence of such specialists in the remaining half of the cases. After examination of the investigative strategy of each police investigation, it is evident that a strong correlation exists between the focus on financial matters at the beginning of an investigation and the presence of professional launderers. Similarly, Brown's study (2013) shows that financial investigation does play a supportive role for other methods of investigation and leads to a conviction.

William (2012) advises that efforts to deter organized crime need to include support for the establishment of ad hoc enforcement agencies, infiltration of criminal networks, targeting of proceeds of crime, and statutes allowing prosecution for conspiracy or racketeering offences. It appears that Papaleo had worked along these lines. He succeeded in infiltrating a criminal network, in contrast to the slower initiative of the Slovak police.

\section{THE AML IN THE EU, SLOVAKIA AND HONG-KONG}

A thorough assessment of the case in hand, and identification of the roles played by both journalists and state authorities, would depend on answers to some highly rel- 
evant questions: What is the status of the AML regime in the EU in general and in Slovakia in particular? Why did the money laundering attempt take place in HK? Why did the Slovakian police refrain from considering this case further, whereas the HK police and judiciary concluded that this was a clear attempt at money laundering?

If the Slovakian police were justified in rejecting this case - as further analysis suggests - then the problem lies within the legislation. Another debatable point is that if Slovakia is a member of the EU, how could such a lapse be possible? Does it mean that the EU has a weak AML legislation? If this is indeed so, then the media/ journalists are wasting time and effort in attempting to expose and avert attempts at money laundering or high crime in general.

\section{AML in the EU}

Addressing the issue of AML legislation in the EU, rules in this area are largely based on international standards adopted by the Financial Action Task Force (FATF). FATF is the principal global body handling problems like money laundering, financing of terrorism or other forces that threaten the stability and integrity of the international financial system.

The third EU Money Laundering Directive is itself quite satisfactory, and every member state was obliged to incorporate it into its legislation by December 15, 2007. Strangely enough, it was only in May 2015 when the Lower Chamber of the Czech Republic passed the legislation that declared attempts at money laundering as a criminal offence (CT2 teletext, May 21, 2015). According to Lacko (2015), with due respect to the criminal legislation concerning AML, possibly a lack of harmony among EU member states has led to occurring differences. Using the Czech Republic as an example, the act of legalisation of criminally acquired income constitutes a criminal offence even in the event of negligence. Consequently, the threshold for establishing criminal liability would be lowered, without needing to prove the intention of the offender; it would suffice that the concerned individual should be aware (according to the circumstances of the case) that legalisation has taken place.

\section{AML in Slovakia}

The offense of money laundering in Slovakia comes under the purview of two legislative acts:

(i) The Slovakian Criminal/Penal Code expects physical existence of money of dubious origin at a particular time. In other words, no attempt at money laundering is actually expected or, at least, the money to be laundered must be first clearly identified. Based on the Penal Code (Section 234), a bank should issue warning signals after the money was laundered via foreign banks.

(ii) The third EU Directive was exclusively implemented in Slovakia with Act No. 297/2008 Coll. on the prevention of money laundering and terrorist financing. 
It does give sufficient space for the police to investigate suspicious activities related to the legalisation of proceedings against criminal activity as the money to be laundered does not have to be necessarily present or transferred in such a case.

The basic distinction between the AML Act and the relevant provisions of the Penal Code is in the purpose of the legal regulation. The AML Act is an administrative statute which regulates the duties of financial institutions and other relevant professions with the objective of prevention and detection of the offense of money laundering. In case of a breach of the AML Act provisions, a fine may be imposed on the concerned institution. This can happen even in the absence of money laundering, if the institution fails to implement any program for combating AML, when it desists from reporting a suspicious transaction, or if it does not verify the identity of the customer. On the other hand, the Penal Code regulates the criminal aspect of anti-money laundering by defining the criminal offenses of legalisation of criminally gained income and the resultant prison sentence. The AML Act and the Penal Code operate in parallel, however, it does not mean that a certain activity has to fall within the jurisdiction of both. For example, failure to draft an adequate internal program for combating money laundering may result in imposition of a fine, although this omission does not constitute a criminal offense (Lacko, 2015).

\section{AML in Hong Kong}

All Asian states except North Korea have signed the AML legislations, and have established a regional institution - the Asia-Pacific Group on Money Laundering - to promote and oversee the implementation of 40 Recommendations of the FATF in the region (Hameiri \& Jones, 2015). The reason behind Jariabka's attempt at money laundering in $\mathrm{HK}$ was simple - the members of his criminal gang transferred the money to various bank accounts of non-existent companies in HK in the form of "loans". Moreover, HK remains the second most secretive country in the world according to the Financial Secrecy Index 2015 (Tax Justice Network, 2015).

After Jariabka's trial was over, Standard Chartered PLC, a bank which was involved in this case, created the Board Financial Crime Risk Committee with the Board-level overseeing authority of the Group's financial crime compliance program since January 2015 (Standard Chartered forms..., 2014). It can be inferred that this was the beneficial result of the case. It is possible that the bank is innocent, as there was no transfer of money, although Papaleo claimed that he submitted invalid documents while opening bank accounts.

\section{THE SLOVAKIAN AUTHORITIES IN JARIABKA'S CASE}

It is a matter of speculation as to why the Slovakian police, in its implementation of the third EU Money Laundering Directive, was so different in its substance from the approach of the HK police and judiciary, as the Slovakian courts certainly did 
not deal with this case. It therefore became essential to check reports from the Office of Attorney General and the Financial Intelligence Unit of the National Criminal Agency of the Presidium of the Police Force (FSJ). FSJ is one part of a global network of Financial Intelligence Units, the main task of which is the application of international standards of the FATF in the area of combating money laundering and terrorist financing. The Office of Attorney General is an independent government authority which protects legal rights and interests of individuals, legal entities and the state.

The National Reports published annually by the Office of Attorney General pay great attention to AML activities (PG, 2014). The Annual Report mentions that the Slovakian legislation is at a somewhat lower hierarchy in the AML, while the AML was still not in accordance with the expectations of the $\mathrm{CoE}$ - Moneyval Group (PG, 2014). It appears that the problem occurred in the absence of coherent and unified statistical output for all the public authorities related to the various cases of procedural legalisation of criminal activity (FSJ, 2014). Curiously enough, considering that the HK money laundering attempt was supposed to include money originating in the Czech Republic, it is interesting to note that the Joint Investigative Team was established for a two year period in May 2013, specifically between Slovakia and the Czech Republic. This body was set up for tackling issues similar to the case study under review. Again, it is debatable whether the co-operation between the two nations was genuinely effective.

The National Criminal Agency refused to comment on the questionable decision of the police investigator about the HK case (NKA, 2015a, b). When the Office of Attorney General was approached for further details, the Office of Special Prosecutor provided an answer on July 17, 2015, validating the verdict of the Slovakian police for a dismissal of this case as:

[...] no conclusion was found about the happening of any criminal activity from which an income or property could appear again as a property or income in line with the law. (p. 2)

Was the lack of legal force or unwillingness to punish Jariabka in Slovakia linked to the high number of suspicious financial operations? In other words, were there perhaps too many dubious cases to investigate properly? According to its Annual Report, the FSJ received 3,886 reports on unusual transactions in total in 2013, and surprisingly, the authors of the report were well aware of the dubious role of the HK banks during that period (FSJ, 2014). The Annual Report claimed that the persons performing the transactions in such a sophisticated manner were citizens of Hungary or Romania, and most of the aggrieved people were of French nationality. Furthermore, in one case, the FSJ in cooperation with law enforcement authorities managed to secure the transferred "funds", and in the second case, after the targeted postponement of funds by the FSJ to "the bank account prepared in advance", the account holder returned the funds which prevented the shift of the income from 
criminal activity to other overseas bank accounts. The following chart (Table 1) of the FSJ $(2014$, p. 8$)$ provides a comprehensive overview of the procedures and decision-making activities of police officers, as well as information submitted within the purview of the Criminal Procedure Code. The table throws light on some glaring facts: the relatively low amount of seized money recovered throughout the year from seven cases, in comparison to the money stolen and subjected to the laundering attempt in this single case (46 million EUR) (Tezkyprachy, 2014).

Table 1. Procedures and further steps of law enforcement authorities in 2013

\begin{tabular}{|l|c|}
\hline \multicolumn{1}{|c|}{ Procedures / further steps of LEAs } & Number of cases \\
\hline $\begin{array}{l}\text { Commencement of criminal proceedings, Section 199 (of Code of Criminal } \\
\text { Procedure) }\end{array}$ & 26 \\
\hline $\begin{array}{l}\text { Commencement of criminal proceedings for Legalisation of the Proceeds of } \\
\text { Crime pursuant to Section 233 and 234 }\end{array}$ & 6 \\
\hline Commencement of criminal proceedings for different crimes & 22 \\
\hline Indictments pursuant to Section 206 & 1 \\
\hline $\begin{array}{l}\text { Indictments for Legalisation of the Proceeds of Crime pursuant to Section 233 } \\
\text { and 234 }\end{array}$ & 0 \\
\hline Indictments for Credit Fraud pursuant to Section 221 & 2 \\
\hline $\begin{array}{l}\text { Dismissal of commencement of criminal proceedings pursuant to Section 197 } \\
\text { (1) (d) }\end{array}$ & 8 \\
\hline Seizure of the funds pursuant to Section 95 & 7 \\
\hline Total amount of the seized funds & $5,691,638$ EUR \\
\hline
\end{tabular}

Source: Annual Report 2013. Financial Intelligence Unit.

Unfortunately, a combination of the Penal Code and AML Act resulted in an inability to use the tip and evidence provided by Papaleo to follow the same legalcriminal path as the HK authorities. According to our verification with two independent lawyers (Lacko, 2015; Kukliš, 2015), the application of the AML Act and the Penal Code in Jariabka's case was correct. As already mentioned, these two separate statutes regulate different aspects of AML. The AML Act regulates the administrative side of the issue, and the threshold for establishing liability is lower. According to Section 2(2) of this act, the knowledge, intent and purpose may arise from the objective circumstances of the case with lesser considerations influencing the decision of punishment. In direct contrast, the Penal Code requires the intent of the offender to be proven.

Mugarura (2014) is probably correct when he concludes that unless states first align themselves properly with pervasive global changes and challenges, they risk being continuously sidelined (swamped). This is not to say that no progress exists within the dimensions of criminal law and judicial cooperation in the EU. However, there are some legal and practical problems with integration of anti-criminal 
agencies into the national legal orders of the member states (see Luchtman \& Vervaele, 2014). Therefore, national authorities must act more effectively against international crime. One can add that pitfalls do exist with AML in Slovakia. According to Lacko (2015), with regard to criminal liability, the Penal Code could be amended to include the criminal offense of negligent legalisation of criminally gained income. The issue is, however, whether this amendment would improve criminal prosecution of the relevant cases, and whether the focus should be classified as cases of negligence.

\section{MEDIA COVERAGE OF THE CASE}

With the drama being enacted by players of differing nationalities and in countries across the globe, it is entirely natural for international media coverage of the story to be rather unusual. The incident was reported as a criminal court case with a journalist in a double role - as a key witness as well as a key source of information. It is however difficult to make generalisations about the role of Papaleo as a reporter/ facilitator (positive role) type of investigative journalist, since the event inspired a varied number of articles.

The scandal was rather differently covered by the media in various countries (till August 2015):

(i) HK - The appeal of the topic in the local context called for wider media coverage of the story in HK compared to other countries which had anything in common with the case. Among the HK media, the story was well covered by the South China Morning Post (International Edition), which published key statements straight from the court supported by photographs from the courtroom. Altogether, the paper published 14 articles written by four authors, including one by the main actor, Papaleo. Other HK media, including one TV channel, accounted for a total of ten news items.

(ii) Italy - From the perspective of the Italian journalists/media, Papaleo is native to Italy and adopted the name of a notorious, though fictitious, mafia gang leader. Media coverage by the Italian media, however, was lukewarm, with less than 10 contributions related to this topic.

(iii) Slovakia - The interest and curiosity stemming from this issue may be attributed to the fact that the money launder Jariabka originated in Slovakia, and Papaleo's trap was also set there. Despite the local context, the coverage of this story was very scarce in the majority of the Slovakian media. The web portal of tabloid topky presented five substantial articles on this topic, while the daily Sme and online version of the daily Nový čas published just one article each on the topic. An online search of the websites of the daily Pravda and business daily Hospodárske noviny indicated that neither of them had reported the incident in any way, which is extremely puzzling. Could it be that the respective editors dismissed the incident as insignificant and with poor appeal to the readers? 
(iv) Czech Republic - Surprisingly, only scant mention of the scam occurred in the Czech media, although the stolen money was supposed to have come from this country. The Czech media merely highlighted the events surrounding the investigation, and a financial cooperative was promptly shut down following a national bank audit. The global implications of the criminal act were touched upon very briefly, or not at all. For instance, Mladá fronta DNES brought out six articles, of which only one referred to the international dimension of the crime. Lidové noviny issued nine reports about the collapse of the financial cooperative, but there was no mention of international consequences. The Czech business newspaper Hospodárské noviny published the maximum number of articles (142), yet again, only a few of them regarded the crime as one with far reaching (literally and figuratively) effects. These findings suggest that the Czech media preferred to focus on the domestic aspects of the case, and it was left to the business orientated newspaper to pay consistent and detailed attention to the story.

Overall, the events were tided over uneventfully (from the media perspective), without any attempt to squash publicity, although Papaleo himself believes that there were at least two such instances, and feels under threat ever since. The first instance took place on the opening day of his testimony, when Papaleo was threatened by the deputy head of the Slovakian diplomatic mission to Beijing, China. During a brief court recess, the man allegedly displayed aggression towards Papaleo, "staring at him for about 10 seconds". Following the incident, the judge ordered the police to make "appropriate inquiries". Papaleo links this incident to the possibility of some top level Czech and Slovak politicians being behind the money laundering attempt. The second unpleasant experience occurred in Thailand where he and his girlfriend faced a life-threatening attack at the time of the court hearing in HK, in 2014. Papaleo was attacked by a group of teenage motorcyclists who took away his laptop and money. The local Thai police failed to find any links with the international money laundering case. Even if this attempt was aimed at harming the journalist in lieu of his involvement in the criminal case, it could have been a revengeful act rather than an attempt to influence or suppress the coverage of the case. Clearly, killing a key witness would only make the topic more sensational for the media and this attempted murder was indeed widely publicized. Reporters without Borders launched an appeal for his safety, to which the Thai police responded by assigning a 24 -hour private security guard for the hospitalized journalist. The role of inactive/lazy (negative role) type of journalist/media can be assigned to all the other journalists and media that failed to give any importance to this particular scandal, which was a single-handed effort toward exposing reality. Partial analysis of such behavior has been presented in the previous pages, but to address this aspect once again, it may be said that the location of the drama was geographically too distant for a prolonged sustenance of interest in the relevant countries. Moreover, Jariabka was relatively unknown in Slovakia, both as journalist and businessman. Papaleo received some financial help from international jour- 
nalistic organizations after the case became public; however, the funds were rather insufficient and, as a token of appreciation, Papaleo certainly deserved better.

It should be mentioned here that a video with Papaleo talking about this case is available on YouTube, and it has earned more than 10,000 views as of July 28, 2015 (Kauza Hong-Kong, 2015).

\section{CONCLUSIONS}

The present case study is rather unusual, and may be regarded as a deviant or sui generis case demonstrating how a single individual, who is a loosely defined investigative journalist and quasi-freelance private detective without institutional or financial backing, exposed and foiled an attempt of international money laundering. The study is an undeniable illustration of the expanding typology of the role which journalist or media can assume, and which would allow them to deal with a corruption case rather than merely report it.

The case was extensively covered in Hong Hong in both English and Mandarin, and also in Thailand and Italy. Media houses located in the original starting point of the dramatic event, Slovakia and the Czech Republic, were either guarded or tepid in their response which resulted in a very modest coverage of the incident. No major legal or personal consequences were visible in Slovakia, nor did the scandal become the subject of vociferous public or political debate. Hong Kong reacted promptly by introducing strictures in their local banks as a protection against money laundering attempts. The major outcome of the incident was definitely the imprisonment of the kingpin, or "journalist/businessman", in Hong Kong, following a court trial in the state.

The lesson learned from the episode is that a journalist can, by the strength of his own determination and initiative, become an "initiator", and reveal and revert what would otherwise have become a major corruption issue of international dimensions. The role of facilitator played by Slovakia due to its liberal working conditions for journalists - in contrast to some other countries like Italy - should not be ignored. At the same time, this may not have been absolutely necessary as there is a minimal likelihood that the sentenced Jariabka would have asked Papaleo to prove his credentials.

Upon analysis, at least two politically and socially pertinent aspects of this case have given rise for concern. In the first place, politically, there was a clear deficiency in the AML Act. Despite having a specialized police agency, multinational and bilateral cooperation in AML, and access to many sources of information including the proceedings of various conferences and seminars on AML, the police and prosecutors in Slovakia were prevented from performing their duty by the nature of this very legislation. If it had not been for Papaleo, Jariabka may have succeeded in laundering the stolen money in Hong Kong. Some criminals connected with the case were arrested by the Czech police, which was in constant touch 
with the Slovakian police. The whereabouts of the stolen money, however, still remains a mystery.

Other factors can also evince different results regarding AML in both $\mathrm{HK}$ and Slovakia: (a) the substantive provisions (defining what constitutes the criminal offense of legalisation); (b) the procedural rules (e.g. the admissibility of evidence), and (c) the actual application of law by the authorities. Moreover, one case can hardly form a basis for solid comparison.

Secondly, and socially, the matter of concern is the fate of Papaleo, who did not benefit from his investigative and crime preventing endeavor. A more systematic approach is needed in order to help independent investigative journalists, such as the possibility of a substantial monetary reward, or awarding them a percentage of the total amount saved. Such a system of reward actually forms part of Slovakian anti-corruption legislation which was passed after completion of this case. It is unfortunate that Papaleo will not be able to benefit from this law in any way, although it is certainly hoped that several other investigative journalists will do so in the future.

\section{REFERENCES}

Brown, R. (2013). Reaching the parts other investigations cannot reach: Securing convictions for organised crime through financial investigation. Journal of Financial Crime, 20 (3), pp. 259-266.

Ethic Net. (2011). Charter of Duties of Journalists. Retrieved April 25, 2016 from http://ethicnet.uta. fi/italy/charter_of_duties_of_journalists.

FSJ. (2014). Annual Report 2013. Financial Intelligence Unit. Retrieved April 12, 2016 from http:// www.minv.sk/?informacie-o-cinnosti-1.

George, A.L., Bennett, A. (2004). Case Studies and Theory Development in the Social Sciences. Cambridge: Harvard University.

Hameiri, S., Jones, L. (2015). Regulatory regionalism and anti-money-laundering governance in Asia. Australian Journal of International Affairs, 69 (2), pp. 144-163.

Hyett, N., Kenny, A., Dickson-Swift, V. (2014). Methodology or method? A critical review of qualitative case study reports. Int J Qual Stud Health Well-being. DOI: 9: 10.3402/qhw.v9.23606.

Kauza Hong-Kong. (2015). Retrieved from https://www.youtube.com/watch?v=Cro_Jr7R1JQ.

Kukliš, L. (2015). Telephone conversation with Dr. Luboš Kukliš, August 14, 2015.

Lacko, P. (2015, August 17). Vec: Odpoved’ na otázky ohladom právnej úpravy týkajúcej sa zákazu prania špinavých peňazí [Answer regarding the question about legal definition of anti-laundering legislation]. Personal correspondence.

Levi, M., Reuter, P. (2006). Money laundering. Crime and Justice, 34, pp. 289-375.

Luchtman, M., Vervaele, J. (2014). European agencies for criminal justice and shared enforcement. Eurojust and the European Public Prosecutor's Office, 10 (5).

Malm, A., Bichler, G. (2013). Using friends for money: The positional importance of money-launderers in organized crime. Trends in Organized Crime, 16 (4), pp. 365-381.

Metyková, M., Císařová, L. (2009). Changing journalistic practices in Eastern Europe. The cases of the Czech Republic, Hungary and Slovakia. Journalism, 10 (5), pp. 719-736.

Mugarura, N. (2014). Has globalisation rendered the state paradigm in controlling crimes, anachronistic?: The notion of borders, state and new crime typologies. Journal of Financial Crime, 21 (4), pp. 381-399. 
Nicholson, T. (2001). Investigatívna žurnalistika na Slovensku: nátlak na zneváženie etiky [Investigative journalism in Slovakia: Pressure towards lowering ethical standards]. In: Nagyová, I., Nižňanský, E. (eds.). Korupcia na Slovensku a jej spracovanie v médiách [Corruption in Slovakia and Its Elaboration in the media]. Bratislava: TIS and CIJ, pp. 103-105.

NKA. (2015a, June 19). Uznesenie PPZ-548/NKA-FP - BA 2013 [Decision PPZ-548/NKA-FP - BA 2013].

NKA. (2015b, May 11). Letter from the National Crime Agency, Bratislava, letter no. PPZ-NKAJFPI-298/2015.

Ondrejkovič, P., Majerčíková, M. (2012). Vysvetlenie, porozumenie a interpretácia vspoločenskovednom výskume [Explanation, Understanding and Interpretation in Social Sciences Research]. Bratislava: Veda.

OSP. (2015, July 17). Upovedomenie o vybavaní podania [A notification about the results of an inquiry].

Petková, Z. (2013). Zuzana Petková: Investigatívna žurnalistika je ako policajná práca [Investigative journalism is like a Police work]. Retrieved April 12, 2016 from http://www.attelier.sk/zuzanapetkova-investigativna-zurnalistika-je-ako-policajna-praca/.

PG. (2014). Správa o činnosti prokuratúry Slovenskej republiky za rok 2013 [Report on activities of the Office of the Prosecutor General in 2013]. Retrieved April 12, 2016 from http://www.genpro. gov.sk/spravy-o-cinnosti-12b7.html.

SCMP. (2014, September 8-9). Slovak businessman sentenced to 4 years' jail in international money laundering case. Retrieved April 25, 2016 from http://www.scmp.com/news/hong-kong/article/158794 (5/slovak-businessman-sentenced-4-years-jail-international-money.

Školkay, A. (2001). Strážcovia cností a žurnalistika morálneho rozhorčenia. Investigatívna žurnalistika a jej základné prvky [Watchmen of virtues and journalism of moral outrage]. In: Nagyová, I., Nižňanský, E. (eds.). Korupcia na Slovensku a jej spracovanie v médiách [Corruption in Slovakia and Its Elaboration in the Media]. Bratislava: TIS and CIJ, pp. 81-87.

Soudijn, M.R.J. (2014). Using strangers for money: A discussion on money-launderers in organized crime. Trends in Organized Crime, 17 (3), pp. 199-217.

Štetka, V., Örnebring, H. (2013). Investigative journalism in Central and Eastern Europe. Autonomy, business models, and democratic roles. The International Journal of Press/Politics, 18 (4), pp. 413-435.

Suphachalasai, S. (2005). Bureaucratic Corruption and Mass Media. University of Cambridge: Environmental Economy and Policy Research Discussion Paper Series.

Tax Justice Network. (2016). Financial secrecy index. Retrieved April 25, 2016 from http://www.financialsecrecyindex.com/.

Tezkyprachy. (2014, October 11). Podílel se na tunelování MSD. Ted'byl odsouzen v Hong Kongu za praní špinavých peněz. Retrieved April 25, 2016 from http://www.tezkyprachy.cz/podilel-se-natunelovani-msd-ted-byl-odsouzen-v-hong-kongu-za-prani-spinavych-penez/.

Topky.sk. (2015, January 16). Exkluzívny Rozhovor s Talianom, ktorý dostal do basy Slováka za pranie špinavých peňazí!. Retrieved April 25, 2016 from http://www.topky.sk/cl/10/1450275/EXKLUZIVNY-ROZHOVOR-s-Talianom--ktory-dostal-do-basy-Slovaka-za-pranie-spinavychpenazi-.

Unger, B. (2013). Can money laundering decrease? Public Finance Review, 41 (5), pp. 658-676.

Unger, B., Hertog, J. (2012). Water always finds its way: Identifying new forms of money laundering. Crime, Law and Social Change, 57 (3), pp. 287-304.

Williams, G.W.E. (2012). Policy implications of different theoretical approaches to organised crime. Journal of Financial Crime, 19 (4), pp. 400-409.

Žitný, M. (2004). Milan Žitný: Investigatívna žurnalistika u nás chýba [Investigative Journalism is Missing]. Retrieved April 12, 2016 from http://hn.hnonline.sk/prilohy-197/milan-zitny-investigativna-zurnalistika-u-nas-chyba-140542. 